for members of the Society and the Press only. Discourses will be delivered by eminent men of seience on four days of the Exhibition, and the prize-winning models of the Society's annual Craftsmanship and Draughtsmanship Competition will be on show. A handbook of the Exhibition, containing full descriptions of all exhibits, will be available early in March from the Physical Society, 1 Lowther Gardens, Prince Consort Road, London, S.W.7.

\section{Chemical Aspects of Cell Division}

THE Manchester Section of the Chemical Society, in conjunction with the Institute of Petroleum, the Poyal Institute of Chemistry and the Society of Chemical Industry, is holding a symposium in the University of Manchester on March 15 on "Chemical Aspects of Cell Divisior.". The speakers and their subjects are: Prof. A. Haddow, "Recent Developments in the Study of Cytotoxic and Carcinogenic Action"; Dr. W. C. J. Ross, "Cytotoxic Action in Relation to Chemical Reactivity"; Dr. F. L. Rose, "Cytotoxic Action in Relation to Molecular shape"; Prof. J. N. Davidson, "Chemical Components of the Cell" ; Prof. W. T. Astbury, "The Problem of the Collaboration between Proteins and Nucleic Acids"; Dr. W. M. Dale, "The Indirect Aetion of X-Rays on Aqueous Solutions of Biologically Active Substances, and the Specificity of the Radiation Effects" ; Prof. E. C. Dodds, "The Application of Biological Research on Hormones, with Special Reference to the Cancer Problem". The chaimen of the three sessions will be Profs. A. Haddow, J. W. Cook and E. R. H. Jones. Further particulars can be obtained from Dr. M. A. T. Rogers, Imperial Chenical Industries, Ltd., Dyestuffs Division, Hexagon House, Blackley, Manchester 9.

\section{Colonial Service: Recent Appointments}

THe following appointments in the Colonial Service have recently been announced: Miss E. A. Blundell (woman education officer, Kenya), head of science side, Kenya High School; Dr. J. I. Taylor (veterinary research officer, Uganda), chief veterinary research officer, Uganda ; J. H. Haughton (agricultural officer grade 2, Jamaica), senior agricultural officer, Jamaica ; H. O. Walker (meteorologist, East African Meteorological Department, Kenya), senior meteorologist, Nigeria ; H. B. Ambrose, agricultural officer, Kenya; J. L. Clacey and J. T. W. Gray, agricultural officers, Gold Coast; J. F. Conroy, agricultural officer, Nyasaland; R. M. Davis, agricultural engineer, Nigeria ; R. F. Le Duc, agricultural officer, Tanganyika; J. D. Carter and O. L. Lewis, geologists, Nigeria; W. Manning, geologist, Tanganyika; G. R. C. Morgan, geologist, Federation of Malaya; J. B. McLean, veterinary officer, Nigeria; E. C. Clarke and A. C. A. Walker, assistant conservators of forests, British Guiana; A. Fraser, assistant conservator of forests, Nigeria; I. H. Proverbs, livestock officer, Nyasaland.

\section{Royal Commission for the Exhibition of 1851}

Mr. W. D. SturCH, secretary to the Royal Commission for the Exhibition of 1851, writes: "I have read with interest Captain Edgar C. Smith's article on 'Scientific Centenaries in 1951' (Nature, January 6, p. 7) ; but may I add one small comment. $\mathrm{He}$ ends his reference to the 1851 Exhibition with these words: 'Fortunately, the Exhibition made a handsome profit, a part of which was used to purchase the market gardens to the south of Hyde Park, a tract of land now partly covered by some national museums which will play a part in the Festival of Britain'. This is a somewhat summary dismissal of the Science, Geological, Natural History and Victoria and Albert Museums; and it ignores entirely the Imperial College of Science and Technology and the Royal Colleges of Music and Art which are also on the estate. Finally, it would perhaps be worth a mention that the present 1851 Senior Studentships and Overseas Scholarships for Scientific Research are still financed out of the Great Exhibition profits."

\section{Announcements}

Sir Cyril Hinshelwood, Sir Claude Gibb and Colonel H. C. Smith have been appointed members of the Scientific Advisory Council of the Minister of Fuel and Power; Dr. E. S. Grumell and Dr. H. Hollings have retired from the Council.

Mr. H. A. R. Binney, Under-Secretary at the Board of Trade since 1947, has been appointed director and secretary of the British Standards Institution in succession to the late Mr. Percy Good.

THE following appointments in the University of Birmingham have recently been announced: Dr. $\mathrm{S}$. W. Challinor to be lecturer in microbiology in the Department of Industrial Fermentation; W. H. Husband and E. J. Charles to be lecturers in chemical engineering.

THE third residential national conference of the Institution of Works Managers will be held at South. port during April 13-15. The arrangements are being made mainly by a local committee of members drawn from the Manchester and Merseyside branches of the Institution. Further information can be obtained from the Institution at 67-68 Chandos Place, London, W.C.2.

THE seventieth annual general meeting of the Society of Chemical Industry will be held during July 9-13 at the Imperial College of Science and Technology, South Kensington, London, S.W.7. The theme for this year will be "Water in Industry". The meeting is being organized by the London Section of the Society, under the chairmanship of Dr. A. C. Monkhouse, of the Fuel Research Station. Further particulars can be obtained from the honorary secretary, Mr. E. L. Streatfield, at Filtrators, Ltd., 92 Seymour Place, London, W.1.

A symposium on molecular structure and spectroscopy, sponsored jointly by the Department of Physics and Astronomy of the Ohio State University and by the Division of Chemical Physics of the American Physical Society, will be held in the Department of Physics, Ohio State University, during June 11-15. The interpretation of molecular spectroscopic data as well as methods of obtaining such data will be discussed, and, in addition, there will be sessions devoted to those phases of spectro. scopy which are of current interest. Further particulars can be obtained from Prof. Harald $\mathbf{H}$. Nielsen, Department of Physics, Ohio State University, Columbus 10, Ohio.

Prof. F. E. Fritsch and Dr. J. W. G. Lund are preparing a Freshwater Algal Flora of the British Isles. They would be glad to hear of any unpublished records or of records published in the proceedings of local natural history societies. If the record relates to a rare species or to one new for the British Isles, they would be obliged if material could be sent to Dr. J. W. G. Lund, The Ferry House, Far Sawrey, Ambleside, Westmorland. 